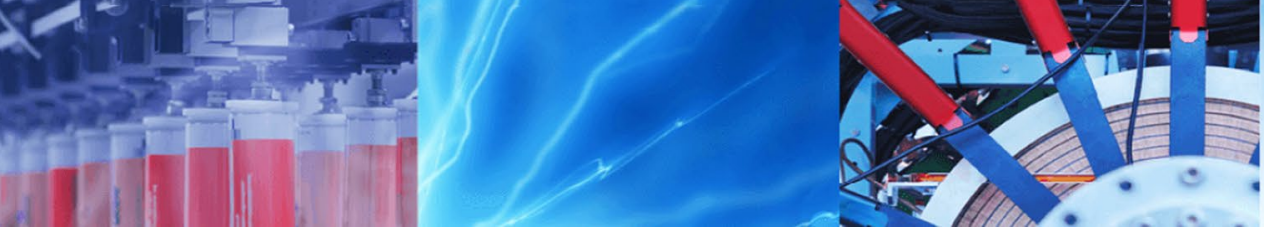

Research Article

\title{
The potential of integrating vehicular emissions policy into Ghana's transport policy for sustainable urban mobility
}

\author{
Prosper Naah Angnunavuri ${ }^{1}$. Francis Atta Kuranchie ${ }^{1,2}$ (1) $\cdot$ Francis Attiogbe $^{1} \cdot$ Esi Nana Nerquaye-Tetteh $^{3}$
}

(c) Springer Nature Switzerland AG 2019

\begin{abstract}
Auto vehicle emissions are a major challenge for ambient air pollution control in most developing countries including Ghana. Major auto emissions, particulate matter, are critical road transport emissions that threaten human health and the environment but are often excluded from policy discussions. In Ghana, vehicle acquisition schemes are not environmentally friendly and current national policies have alienated the monitoring of airborne emissions from the transport sector. This calls for the design and implementation of green transport and fuel economy options. We discuss the critical role of motor vehicle particulates in Ghana and propose policy solutions for sustainable urban mobility. We have shown that environmental remediation, social equity and sustainability can only be achieved when transport emissions are properly integrated in a coordinated transport policy. Ghana has a National Transport Policy that recognizes the challenges of environmental pollution due to vehicular emissions and uneconomic fuel consumption. There are green fuel policy proposals and a vehicle testing and licensing regime that is largely driven by mechanical and electrical functionality. Auto-vehicle emissions performance standards have not been developed and technical capacity for emissions testing is lacking. Ambient air monitoring is limited to particulate matter which is not nationally representative as it is confined to Greater Accra Region at only 15 sites. $77 \%$ of road users believe $20 \%$ of all cars in urban centres visibly exude fumes. Noise pollution and vehicular emissions were reported at $78 \%$ and $75 \%$ of 160 respondents respectively. Vehicle owners, drivers and driver unions are apprehensive of electric cars but would welcome a reliable, convenient and efficient mass transport system. Abatement strategies to reduce vehicular emissions particulates will require integrated solutions and inter-agency collaboration among regulatory institutions. The Environmental Protection Agency and Driver and Vehicle Licensing Authority should be empowered to develop emissions performance standards and conduct real time monitoring of particulates with the assistance of the Motor Traffic and Transport Department of the Ghana Police Service. It is further recommended that volatile organic compounds, particularly benzene series contaminants, should be monitored by the Agency. Further research on vehicular emissions of volatile organic compounds and their health effects on road users should be carried out to understand the full impact of exposure of on-road emissions.
\end{abstract}

Keywords Ghana · Particulate matter · Fuel economy · Sustainable transport · Urban mobility

\section{Introduction}

Transport policies are key to the development of sustainable cities, social equity, public health safety and sustainable economies [31, 49]. Transportation is a key driver of economic activity and development the world over [78], but also serves as a major source [39] for the emission of various outdoor air pollutants $[31,38,39$, $42,46,66]$ which adversely affect human health and the environment. Road transport is a major contributor of air

\footnotetext{
$\triangle$ Francis Atta Kuranchie, francis.kuranchie@uenr.edu.gh | ${ }^{1}$ Department of Energy and Environmental Engineering, University of Energy and Natural Resources, P. O. Box 214, Sunyani, Ghana. ${ }^{2}$ School of Engineering, Edith Cowan University, Joondalup, Australia. ${ }^{3}$ Manufacturing/Industries Department, Environmental Protection Agency, P. O. Box MB 326, Accra, Ghana.
} 
pollution and climate change in general and contributes significantly to the emissions of greenhouse gases, particulate matter and volatile organic compounds [31, 39, $64,76,84]$. Ghana's National Transport Policy recognises the important role of intermodal transport for sustainable national development but gives very little attention to environmental pollution and adverse human health [17]. The World Health Organization (WHO) recognizes air pollutants as the greatest environmental risk to human health $[44,65,81]$. Air pollution mortality globally has been reported at 7 million people by the Organization with over $90 \%$ of the world's population exposed to stale air [81]. The World Bank asserts that automotive air pollution will increase in developing countries unless pragmatic steps are taken to curb the tide in the midst of increasing urbanization, motorization and energy demand [21,38]. Data from the Institute for Health Metrics and Evaluation (IHME) and the Health Effects Institute (HEI) indicate that the burden of poor air quality weighs more on developing countries in Africa, than most places around the world [32].

Air pollution is a multi-dimensional problem with widespread externalities on climate change and the Sustainable Development Goals (SDGs). The United Nations (UN) Environment estimates that road transport alone contributes $73 \%$ of the $7 \mathrm{GtCO}_{2}$ e by the transport sector [3]. The UN further underscores the importance of air pollution on human prosperity and the health of the planet in its SDGs 3 Target 9, and Goal 11 Target 6 which collectively seek to develop safe, inclusive and resilient cities and ensure healthy lives and wellbeing for persons of all ages [67] through adequate sanitation and air pollution prevention. The Clean Development Mechanism (CDM) [79], and Article 6 of the UN Framework Convention on Climate Change (UNFCCC) [45] all emphasize the need to control automobile emissions as a means to ensure sustainable growth and reduce climate change.

Particulate matter is the most widespread air pollutant globally $[8,47]$ and has been used extensively by the World Health Organization (WHO) as a measure of Air Quality Index (AQI) in its annual Global Burden of Disease, and Air Quality Guidelines: Global Update reports. The United Nations Organization SDGs report on $\mathrm{PM}_{2.5}$ mortality globally has been anything but savagery, with $90 \%$ of the death toll recorded for developing countries [74]. Outdoor fine particulates have been confirmed to be carcinogenic to human. Emissions from mobile sources, especially on-road vehicles, continue to rise $[11,75]$ and contribute significantly to climate change $[41,76]$. Climate change in turn affects long-range transport of environmental pollutants, chemical processing, and local meteorology which can impact airborne diseases, poor visibility and reduction in the aesthetic value of landscapes and infrastructure.
Particulate matter has been shown to contribute to increasing rates of asthma, stroke, ischemic heart disease, chronic obstructive pulmonary disease (COPD), cardiovascular diseases, and lung cancer $[6,37,40,54,71,76]$. Particulate matter pollution has wide and undesirable implications for the health of women and children [7, 29, $30,68,77] . \mathrm{PM}_{2.5}$ in particular has been blamed for the aetiology of diabetes among pregnant women and the elderly $[9,20,33,43,56,76,83]$, and reduces the life expectancy of children [43] especially in developing countries [9]. Children with air pollution-induced neonatal disorders may progress with impaired neuro and cognitive development which can affect their performance in later life [58].

It has been advocated that transport air pollution policies must focus on the most hazardous and prominent species for a particular region and strategies to reduce them [28]. Recent studies in Ghana have identified particulate matter as major contributors of ambient air pollution from energy consumption and transportation $[4,12$, $59,66,73,84]$. This paper seeks to analyze the dimensions of exposure assessment related to vehicular emissions and the role of policy in risk mitigation in a Ghanaian context. The information contained herein may be useful for other developing countries where policy alternatives are limited. The study is particularly important in the face of the Aarhus Convention which seeks to encourage public participation in environmental discourse and public policy under the auspices of the United Nations.

\subsection{Demographic profile of Ghana and environmental sustainability}

Ghana's population is estimated at 28.2 million [82] and continuous to increase at $2.5 \%$ per annum with urban population completely outstripping rural due largely to rural-urban drift of the youthful bracket [18]. Life expectancy is reported at 63.4 years with under-five mortality at 58.8 per 1000 live births [82]. Unsustainable consumption patterns, inefficient human mobility systems, and a fossil-based economy [70] have contributed significantly to higher post-consumption emissions of air pollutants. A recent report on the State of the Environment in Ghana identified the transport sector to be the largest source of air pollution [18]. Key among these pollutants are airborne particulates $\left(\mathrm{PM}_{10}\right.$, and $\left.\mathrm{PM}_{2.5}\right)$, due to their propensity to cause adverse human health. Acute respiratory illness (ARI) and chronic lung disease (CLD), two major cause of air pollution, have been ranked among the first 5 major causes of death in Ghana [2]. Road transport is the dominant mode of mobility in Ghana, contributing over $95 \%$ passenger and cargo traffic [18]. A continually expanding economy and transport has made mobile source air pollution a national problem in Ghana. Transportation is a key 
determinant of health due to the influence of air pollution [13], making it imperative to include air pollution monitoring in transport policies.

\subsection{National policy directives for energy use, transportation and air pollution}

Ghana's transport sector is composed of road, in-land water, maritime, air and rail. The Ministry of Energy (MoE), Ministry of Transport (MoT), and the Ministry of Environment Science and Innovation (MESTI) through the Environmental Protection Agency (EPA) have direct jurisdiction over the design and implementation of policies and governance structures for energy use, transportation and air pollution respectively in Ghana. A broad array of policies guide environmental regulation in Ghana, key among them being the Constitution of the Republic [27], the EPA Act [62], and the National Environmental Policy [18]. The MoT rolled out the National Transport Policy in 2008 with the aim of ensuring roadworthy fleet and motorable roads nationwide. The policy recognises a number of challenges including environmental pollution, emissions of greenhouse gases and unsustainable fuel consumption [17]. Various governmental agencies have implemented agency-wide transport policies to guide the use of their vehicles. Ghana relies largely on road transport with the participation of public and private service operators [34, $61,66]$.

At the Ministerial level of MESTI and MoT, the development of resilient public transport networks including the Metro Mass Transit (MMT), the State Transport Company (STC), and the Aayalolo Bus Rapid Transit (BRT) are key strategies of a transport sustainability scheme for intercity and intra-urban transit in Ghana. In particular, the BRT system is integrated with dedicated bus lanes to improve transit time and lower fuel consumption per unit travel. According to MESTI, and MoT, the Government of Ghana hopes to expand these schemes to other parts of the country to encourage mass transport and reduce traffic congestion. On the specific case of pollutant emissions, the Government is considering a diversified transport regime with road, rail and water transport as key linkages for national development. There are plans to introduce electric cars and high-speed bullet trains to reduce vehicular emissions and enhance the country's progress towards achieving her Nationally Determined Contributions (NDCs) in the broader context of climate change mitigation and adaptation. The Ghana Private Road Transport Union (GPRTU) is the dominant private road transport operator in Ghana. Other private operators include the Progressive Transport Owners Association (PROTOA), Kingdom Transport Services (KTS), and the Ghana Corporative Transport Association.
The National Medium-Term Development Framework (MTEF) aims at developing a sustainable transport system to position Ghana as a transportation hub within the West African sub-region [52]. Unfortunately, the framework fails to integrate environmental pollution with a sector-wide re-development plan. This framework must be retooled to recognize the role of hazardous transport pollutants and align them with the implementation of the strategic policies, regulation of market forces and the efficient supply of services that address environmental and human health challenges in the transport sector.

The Environmental and Sanitation Policy (ESP) of Ghana was designed on the tenets of environmental and economic sustainability to meet the exigent demands for climate change mitigation and adaptation. The policy endorses efficient production and consumption principles and calls for minimum use of raw material resources with minimal waste generation through value addition [62]. Weak governance, lack of political will, institutional incapacity, limited funding and low awareness among the citizenry have debilitated the effective implementation of the policy. The lack of enforcement has provided lacunas for opportunists to unduly exploit to the detriment of the larger population.

The Energy Commission (EC), an agency under the Ministry of Energy, has developed comprehensive national energy policies for energy use in Ghana. Ghana's National Energy Policy seeks to reduce the reliance on non-renewable resources whilst simultaneously increasing the installation and utilization of renewable energy to meet the energy demand for all persons in Ghana. The policy however fails to recognize the important role a fuel-based economy plays in environmental pollution (especially air pollution) and the need for regulation. In 2000, the EC initiated the development of a Strategic National Energy Plan (SNEP) to meet energy demands in a sustainable manner. On the back of the energy strategy, a Bioenergy Policy aimed at $20 \%$ infusion of biofuels into the country's energy mix by year 2030 was implemented in 2010. Though the target has been deemed conditionally achievable [35], recent progress reports by the EC cast doubts on the tenability of the initial estimate [23]. According to the Ghana Renewable Energy Master Plan, current biofuel integration remains at zero although 20,000 tonnes are projected to be produced by 2030 [25]. Be it as is, this integration in addition to tighter gasoline and diesel standards, is expected to significantly reduce vehicular emissions of particulates, and auto-emissions in general. Ghana recently joined the Global Fuel Economy Initiative (GFEI) which aims at reducing fossil-fueled cars and a gradual introduction of electric vehicles and other modal systems [3]. A key promoter of the initiative is its intention to reduce emissions and greenhouse gases from 
the transport sector. Ghana can benchmark progress made through the implementation of the GFEl in South Africa [3] and Mauritius [63] to improve her transport space.

The Ghana Climate Change Policy was developed by the MESTI in 2012 as the nation's climate action blueprint. The policy recognizes the role of transportation and energy use in increasing carbon footprints and the need to develop sustainable production mechanisms to mitigate the impacts of climate change. The climate change policy is expected to provide direction for the achievement of a low carbon economy and sustainable equitable development through a robust climate-compatible economy. The Ghana National Climate Change Master Plan Action Programmes for 2015-2020 also developed by the MESTI recognizes the potential role of sustainable transportation and energy use as tools for achieving the national climate change targets in line with the NDCs. Apart from the National Climate Change Policy, the National Climate Change Adaptation Strategy (NCCAS) and the Nationally Appropriate Mitigation Actions (NAMAS) have also been developed to help curb the dangers of climate change and climate variability. The third report to the UNFCCC in 2015 puts Ghana's total GHG emissions at $18.49 \mathrm{MtCO}_{2} \mathrm{e}$ with $\mathrm{CO}_{2}$ emissions increasing by $82 \%$ over the intervening period of the second report $[15,16,18]$. Although this is comparatively smaller to figures from more developed countries, the increasing levels of $\mathrm{CO}_{2}$ is a concern for stakeholders in Ghana. Global emissions from the transport sector have been projected to rise into the future, and the Center for Climate and Energy Solutions is urging national governments to implement stringent policies from automobile vehicles [14]. Already, climate change is negatively affecting water supply, agriculture, energy production and human welfare.

\subsection{Regulation of energy use, vehicle use and airborne emissions}

The DVLA was established in 1999 by an Act of Parliament (Act 569) to regulate the use of vehicles and promote good driving standards in Ghana. The Act outlaws the use of excessively smoking vehicles that are deemed to be hazardous to other road users. The Act does not include measurable emission performance standards but imposes a penalty on the importation of vehicles older than 10 years. The DVLA currently supervises 36 inspection and testing stations in Ghana. Ghana's vehicular fleet continuous to record year-on-year growth with majority of them within the over-aged and high emitting bracket [72].

The EPA is responsible for all environmental regulations, including standardization, monitoring, assessment, compliance and penalties, in Ghana. The Head of Environmental Quality Monitoring at the EPA concurs that vehicular transport is a major contributor to motorized emissions of particulate matter and volatile organic compounds in the country. Ambient air standards particulate matter and a wide range of air pollutants have been developed [19] but monitoring is limited to $\mathrm{PM}_{2.5}$ and $\mathrm{PM}_{10}$. At present, point source monitoring does not cover motor vehicle emissions. Inadequate monitoring data, and poor institutional capacity of regulatory agencies is a major hinderance to the development of comprehensive national datasets on air quality and proper estimation of the impact of stale air on the environment and human health. Source apportionment inventories are essential to enable decision makers target interventions in pollution abatement efforts. Empirical evidence suggests that particulate matter, especially $\mathrm{PM}_{2.5}$, are key human health hazards emitted largely from motor vehicles. Control of emissions of these pollutants is therefore essential for the assurance of public health safety and proper environmental hygiene.

The Ghana Standards Authority (GSA) is responsible for setting trade standards in Ghana. Fuel standards have been upgraded to the Association of African Refiners category 4 (AFRI-4) standard which provide for $50 \mathrm{ppm}$ sulfur, 1 ppm benzene, and 30\% total aromatics [26]. In collaboration with the EPA, it is important to also develop vehicular emissions standards to monitor their emissions performance. The NPA, and EC are responsible for energy use, regulation and governance in Ghana.

\subsection{Institutional nexus}

The elements of a sustainable transport system are depicted in Fig. 1. The chart assesses the current state of energy consumption and emissions measurement in the transport sector and juxtaposes them with a green approach in which the overall aim is to achieve an integrated fuel, and motor vehicle emissions control regime.

The apparent lack of coordination of fuel standards on the one hand, and ambient air and vehicular emissions control on the other is a key defect in the pursuit of sustainable mobility systems in Ghana. A largely fossilized economy and inefficient energy consumption patterns lead to intense environmental pollution with attendant negative health impacts. Sustainable and preventable pollution options include green energy and transport policies that are sensitive to the environment and that which set standards for emissions performance monitoring. Consideration must be given to non-motorized transport options such as walking, and cycling.

There is an urgent need to upscale the inter-agency collaboration among the MoT, MESTI, EPA, DVLA, GSA, NPA, NRSC, and EC if the objectives of sustainable transport policy are to be achieved. The EPA has to upgrade its monitoring capacity to programs capable 
Fig. 1 Elemental integration of a sustainable transport and mobility systems

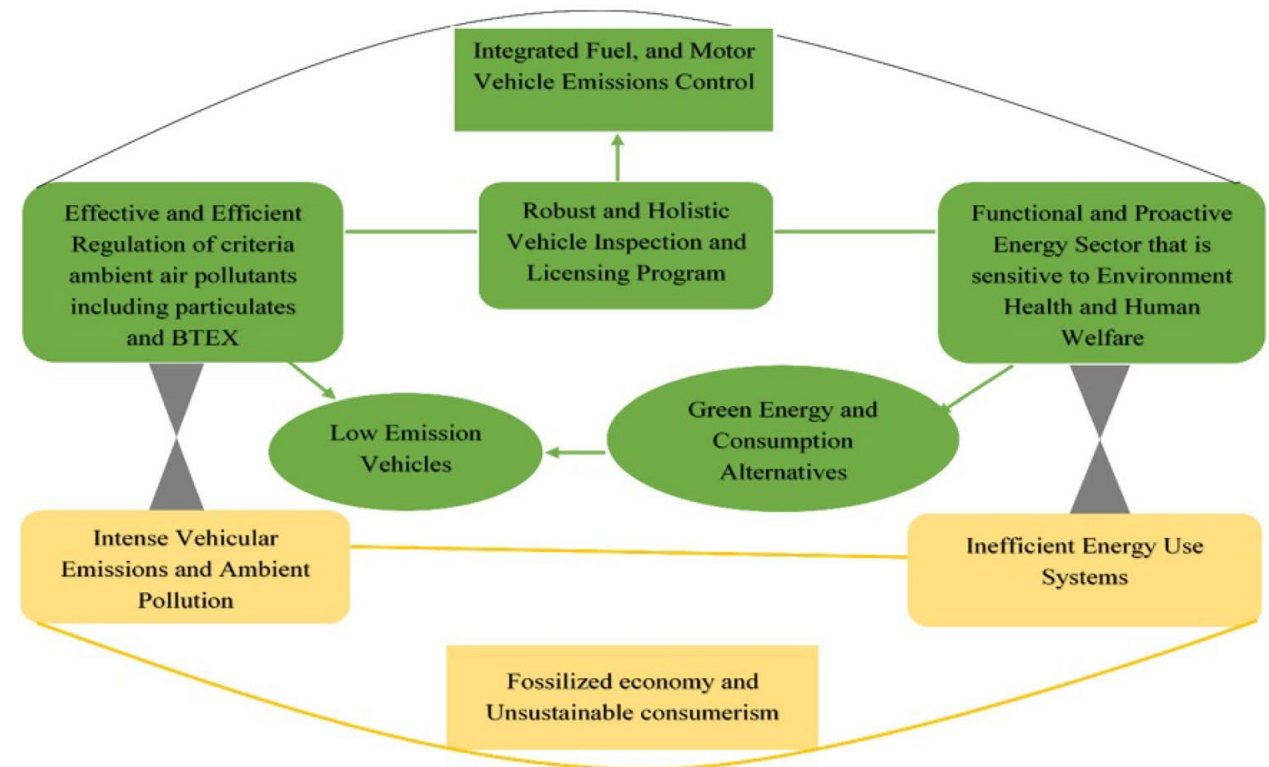

of producing real-time results from simple portable hand-held monitors that can be deployed nationwide. Through an enhanced training programme, the Motor Traffic and Transport Department (MTTD) of the Ghana Police Service can be a key partner in this monitoring campaign to help provide adequate vehicular emissions inventory with the monitors through on-spot checks.

Policy measures are usually inter-related, and it is their combined effect that yield the set objectives. Vehicular pollution depends upon land use planning, transport planning, infrastructure investment, traffic management, fuel quality controls and pricing, mass transport programs, vehicle technology standards and maintenance, tax regimes, and a range of other factors influenced by government policy [48]. Choosing the right combination of green measures, and ensuring that they are implemented properly, is critical to the achievement of the goals of the GFEl. Piecemeal policies can easily work at cross-purposes, incurring high costs to little effect. A coherent strategy, designed in consultation with local stakeholders and supported by an efficient awareness and monitoring system, is more likely to reduce air pollution efficiently and yield economic as well as health benefits. Banister [5] avers that a key ingredient necessary for superimposing a sustainable mobility program over a traditional system is public acceptability. Ghana may need specific regulation for an air quality control commission or an air quality control division of the EPA if a comprehensive national air quality program is to be achieved.

\section{Methodology}

This is an exploratory study. Primary and secondary data was gathered from regulatory agencies including the Ministry of Transport (MoT), the Ministry of Environment, Science, Technology and Innovation (MESTI), the Environmental Protection Agency (EPA), the Driver and Vehicle Licencing Authority (DVLA), driver unions, mobile vehicle occupants, street hawkers, road side shops, and roadside residents through face-to-face semi-standardized interviews. In all 160 interviews which is made up of 25 roadside hawkers, 25 roadside shop attendants, 25 in-car occupants, 25 pedestrians, 25 drivers, 25 roadside residents, 6 transport operators and 4 regulators were conducted. We sought for and obtained historical air quality monitoring data from the MESTI/EPA, and vehicle registration data from the MoT/DVLA. Fuel use data, mainly petrol and diesel were obtained from the National Petroleum Authority and the National Energy Commission. We sought to find out from respondents the current state of auto vehicle ownership and regulation in the country, emissions standards and monitoring, green auto energy use options in Ghana, sustainable mobility outlook and participatory role of vulnerable road users. Participants were asked to self-report and rate the risk factors of their exposure to transport pollutants. The interviews were transcribed into text and analyzed with MAXQDA. Relevant documents and data were also sought from the agencies 
and analysed with Microsoft Excel. Ethical clearance for this study was granted by the Ethics Committee of the University of Energy and Natural Resources (Ghana). All prospective interview participants were adequately informed about the intent and use of the data, and the confidentiality of their responses. Only consented participants were interviewed. The specific and detailed questionnaire in the face-to-face interviews are stated Tables 1 and 2.

\section{Results and discussion}

We present below a brief demographic profile as regards air pollution and a review of the current national policy frameworks that guide energy use, transportation, air pollution and climate change.

\subsection{Responses from institutional interviews}

We obtained archived data from the Ministry of Transport, the Driver and Vehicle Licensing Authority, the Environmental Protection Agency, the National Petroleum Authority, and the Ghana Energy Commission. Results of the data and interviews are presented below;

\subsubsection{Motorization}

Ghana had a total civilian registered vehicular throughput of 2,206,415 as at year end 2017 [53]. These vehicles comprise light and heavy duty, minibuses, buses as well as two and three wheeled motors. Moto tricycles were introduced into the country beginning 2017 when 8174 were registered. The national capital, Greater Accra, accounts for about $60 \%$ of this number, whilst the second largest city, Kumasi, takes up $14 \%$. The remainder is shared by the other regions. Average age of vehicles, excluding buses

Table 1 Questionnaire for drivers and driver unions

\begin{tabular}{|c|c|c|c|}
\hline \multirow[t]{2}{*}{ Q1. Questionnaire for driver unions and drivers } & Driver unions & \multicolumn{2}{|c|}{ Drivers } \\
\hline & No & Yes & No \\
\hline \multicolumn{4}{|c|}{$\begin{array}{l}\text { Current tax regime prorates the import duty depending on the age of the car. Is the current tax regime on auto- } \\
\text { mobile vehicle importation favorable to you }\end{array}$} \\
\hline \multicolumn{4}{|l|}{ Do you think it is environmentally friendly } \\
\hline \multicolumn{4}{|l|}{ Do you think it is sustainable } \\
\hline \multicolumn{4}{|c|}{ According to the DVLA, Ghana's fleet is largely composed of high emitting types. Is this situation fine with you } \\
\hline \multicolumn{4}{|l|}{ Would you like a policy shift to reduce emissions from cars? } \\
\hline \multicolumn{4}{|l|}{ What specifically would like the policy to contain? } \\
\hline \multicolumn{4}{|l|}{ Ban on importation of high emitting vehicles } \\
\hline \multicolumn{4}{|l|}{ High fiscal incentives for importation of green fuel vehicles } \\
\hline \multicolumn{4}{|l|}{ High fiscal incentives for importation of electric vehicles } \\
\hline \multicolumn{4}{|l|}{ Green driving and traffic regulations } \\
\hline \multicolumn{4}{|l|}{ Mass transportation (buses, trains) } \\
\hline \multicolumn{4}{|l|}{ Restricted drive zones in central business districts } \\
\hline \multicolumn{4}{|l|}{ High quality and affordable fuel } \\
\hline Standard road infrastructure compatible with the policy shift & & & \\
\hline
\end{tabular}

Table 2 Questionnaire on determinants of vehicular use in Ghana

\begin{tabular}{|c|c|c|c|c|c|c|c|}
\hline \multicolumn{8}{|c|}{ Influencers of vehicular use in Ghana } \\
\hline Type of transport service & $\begin{array}{l}\text { Utility value } \\
\text { of transport } \\
\text { service }\end{array}$ & $\begin{array}{l}\text { Time to } \\
\text { destina- } \\
\text { tion }\end{array}$ & Convenience & Affordability & Ease of access & $\begin{array}{l}\text { Propensity to } \\
\text { use an electric } \\
\text { car }\end{array}$ & $\begin{array}{l}\text { Propensity to use a } \\
\text { reliable bus transit }\end{array}$ \\
\hline
\end{tabular}

\section{"Trotro"}

Commercial intra-city bus

Private light-duty car

Taxi or other drop-off service 


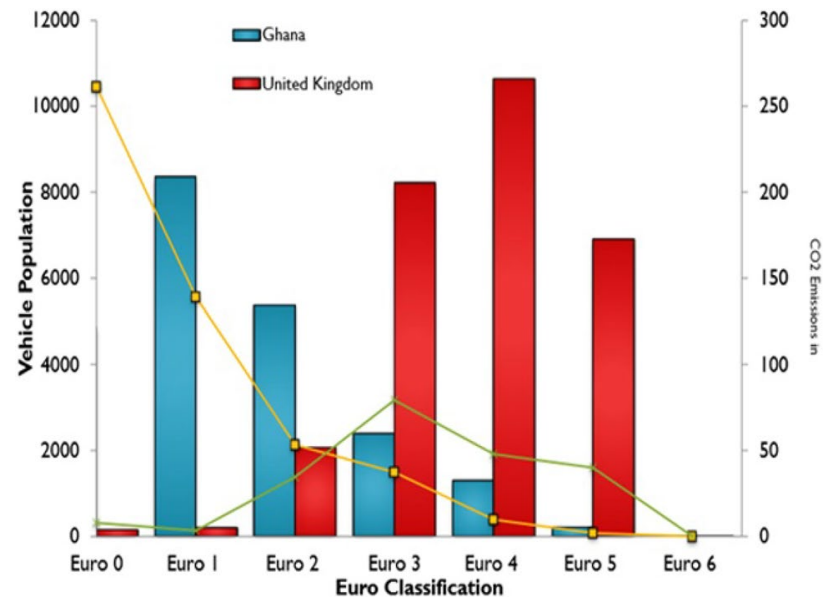

Fig. 2 Comparison of Euro Standards in Ghana and the UK [53]

and coaches, is estimated at 14.2 years with most of them being second-hand cars on first registration. Majority of these vehicles are high emitting Euro 1, and 2 categories, with Euro 5 and 6 constituting the minority, as shown in Fig. 2.

Thus Ghana, and most other developing countries with lower emission standards, have become dumping grounds for banned highly polluting vehicles from Western countries. The growth in vehicular fleet is depicted in Fig. 3.

Demand for transportation continuous to increase with growing economic development over the years. Motorization and road transport have been the dominant form of mobile transport in Ghana, and the trend does not seem to change anytime soon. Ghana relies principally on the importation of both new and used vehicles to meet the country's fleet requirement. A local assembling plant,
Kantanka Automobiles, has started production in the country. Some European brands including Volkswagen and Renault have also registered their intentions of setting up assembling plants in Ghana. These new developments call for new standards by the GSA that must be set to meet local conditions without compromising on the credibility of testing procedures.

The use of private vehicles in the urban centres continuous to rise due to an unreliable public mass transport system, and the influence of a growing middle-income class. Sulemana [72] also attributed the growing demand for cars in Ghana partly to an increasing population, a position earlier articulated by Obeng-Odoom [57]. Inderwildi and King [36] opinionated that personal mobility in urban areas is predicated by factors such as comfort, utility and security.

The unrelenting growth in motorized transport is contributing to severe pollution in urban centres and putting pressure on fuel, land use, and human welfare. Without focussing on environmental pollution, Gakenheimer [22] argued that increasing motorization without commensurate development in allied and support services is a function of declining mobility and destination accessibility in developing countries. Environmental (air) pollution is exacerbated by poor fuel regimes and vehicle types that do not support clean fuel burning.

Ghana's relaxed vehicle acquisition regime does not help with the fight against environmental pollution. It is recommended that the nation caps the age of vehicles imported into the country and also considers clean burning technologies for low emission vehicles. Kenya for instance has limited the age of vehicles imported into the country to 8 years [38]. In order to achieve the objectives of Ghana's Medium-Term Development Framework, it is
Fig. 3 Annual new vehicle registration in Ghana [1]
Automobile New Registrations in Ghana

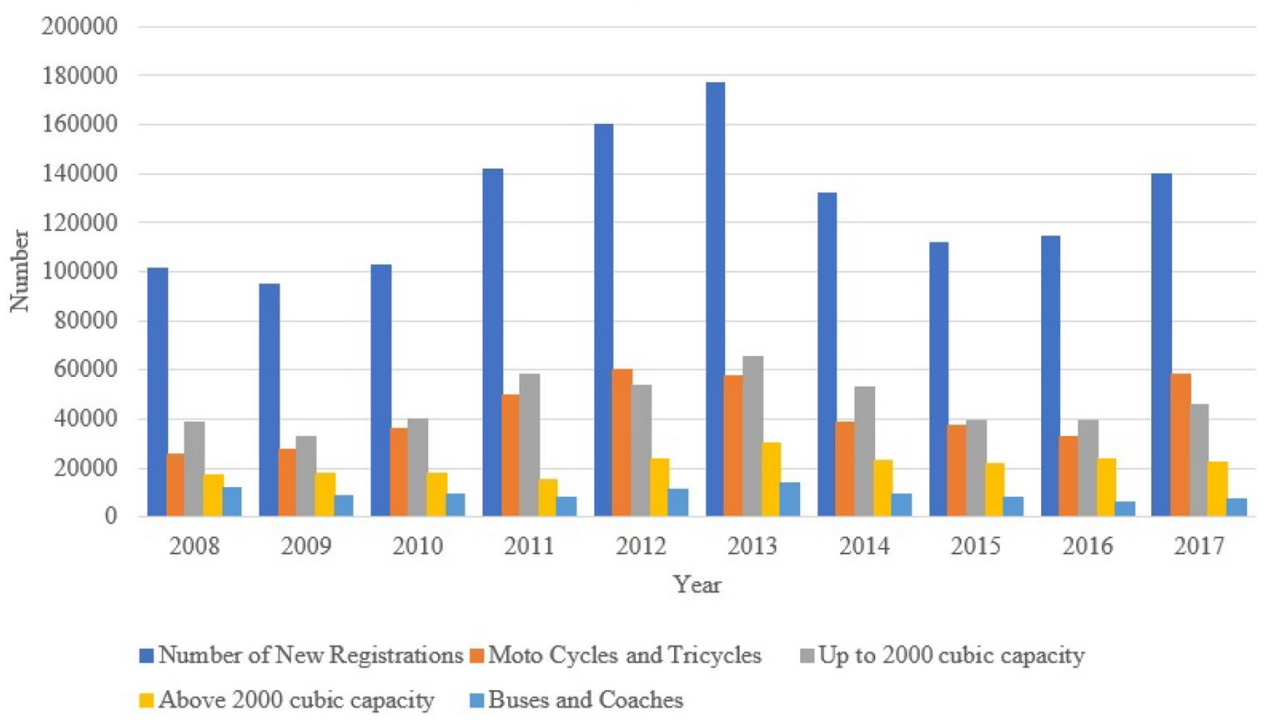


imperative to develop national strategies that provide greener and sustainable transport and fuel use options to protect human health and the environment. Properly costed emission taxes on over-aged vehicles and subsidies for cleaner and brand-new vehicles may be worth considering.

\subsubsection{Motorized fuel use}

Decadal data from the NPA and Energy Commission shows steady increases in the consumption of gasoline and diesel. From a combined total of $1637.1 \mathrm{Kt}$ in 2007 , the figure rose to $2734.1 \mathrm{Kt}$ in 2017 representing $67 \%$ over the period. Within the same period gasoline consumption increased by $98 \%$ and diesel by $52 \%$. Peak consumption occurred in 2015 when $3066 \mathrm{Kt}$ of total fuel was supplied to motorists. The State of the Environment report by the EPA corroborates the excessive appetite for fossils and recommends stringent measures to hasten biofuel integration into mainstream fossil fuels. Figure 4 gives a profile of motorized fuel consumption over the 10-year period in Ghana.

Energy consumption continuous to tilt towards fossilbased fuels, with over $50 \%$ of Ghana's current energy mix sourced from petroleum resources [18]. Ghana is only second to Nigeria in terms of total national energy consumption in West Africa [54]. The petroleum resources are used to power vehicular fleets, power plants, industries and domestic backup power supply systems. The bulk of it though is used to power automobiles, leading to the generation of automotive emissions and exposure of invehicle and vulnerable road users.
The use of Liquified Natural Gas (LPG) as fuel for motor vehicles in recognition of its cleaner burning properties has been established in Ghana since 1994, partly accounting for the about $23 \%$ national penetration between 2000 and 2017 [18, 23]. There are sole LPG-powered cars and hybrid LPG-gasoline vehicles permitted by the MoT. Autogas has been estimated to constitute $37 \%$ of total LPG consumption in Ghana [50], and tends to rise with increasing gasoline and diesel prices [51]. An economic analysis by Simons and Nunoo [69] points to lucrative business opportunities for autogas usage and recommends the fuel for light-duty commercial vehicles. An expanded and incentivised program on vehicular LPG use will speed up achievement of the country's targets on the NDCs and also result in less pollution of the environment.

\subsubsection{Air quality monitoring and human health}

Ghana lacks real-time air quality assessment regime and monitoring. It is limited to only $\mathrm{PM}_{2.5}$ and $\mathrm{PM}_{10}$ at a limited scale. All monitoring sites are located in the national capital, Greater Accra, as shown in Fig. 5.

There are 14 monitoring stations for $\mathrm{PM}_{10}$ and only one station for $\mathrm{PM}_{2.5}$. The limited data on particulate matter exposure shows a deteriorating pattern of the situation especially with roadside monitors [18]. Particulate pollution has consistently remained higher than national standards and international guidelines [80]. In 2016, average roadside $\mathrm{PM}_{2.5}$ exposure was reported by the EPA at $55 \mu \mathrm{g} \mathrm{m}^{-3}$. Average urban $\mathrm{PM}_{2.5}$ pollution in Ghana is reported by the WHO at $31.1 \mu \mathrm{g} \mathrm{m}^{3}$ in 2016 [82]. Within the West African sub-region, the least recorded by the

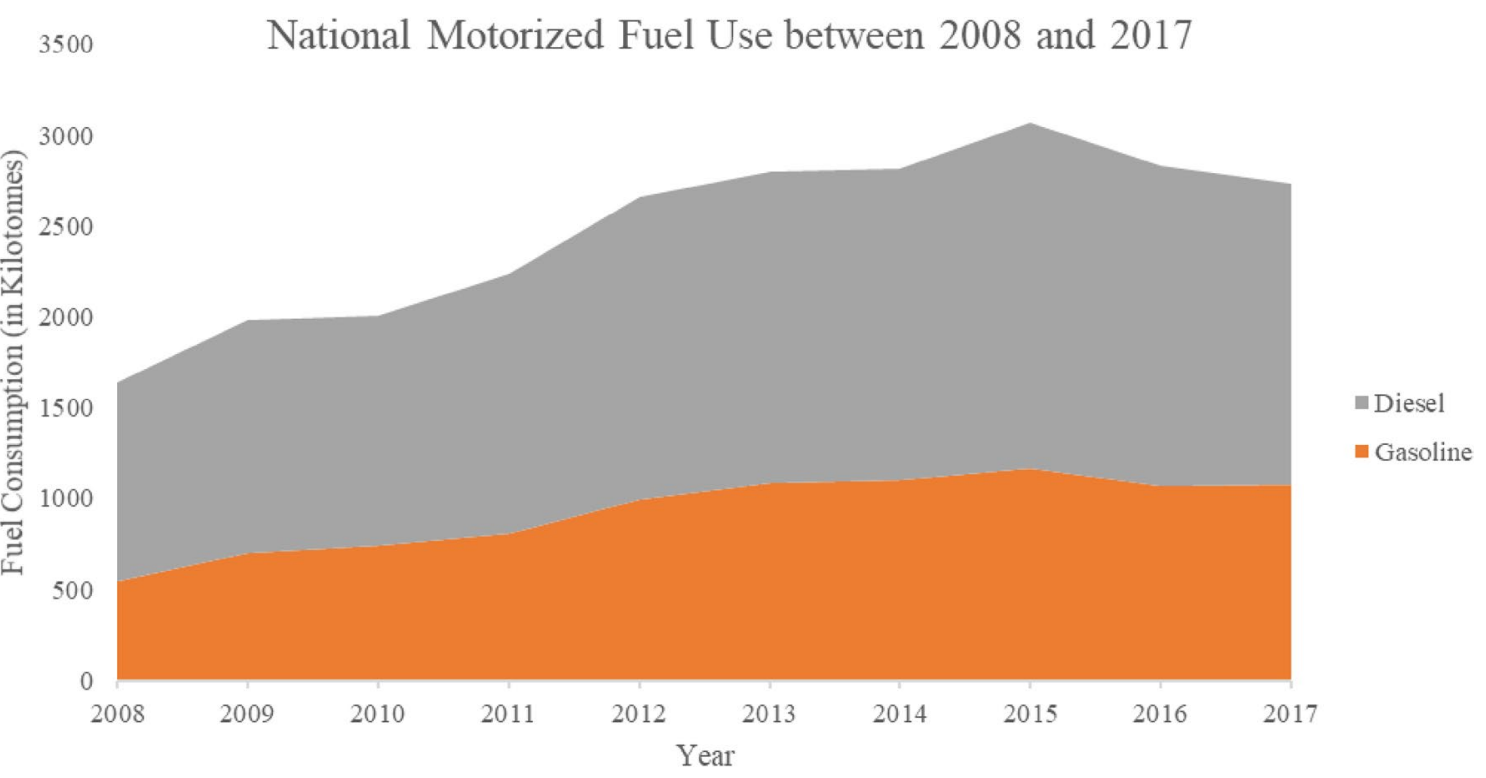

Fig. 4 Fuel use between 2008 and 2017 [24] 
Fig. 5 Particulate matter monitoring locations in Ghana [19]

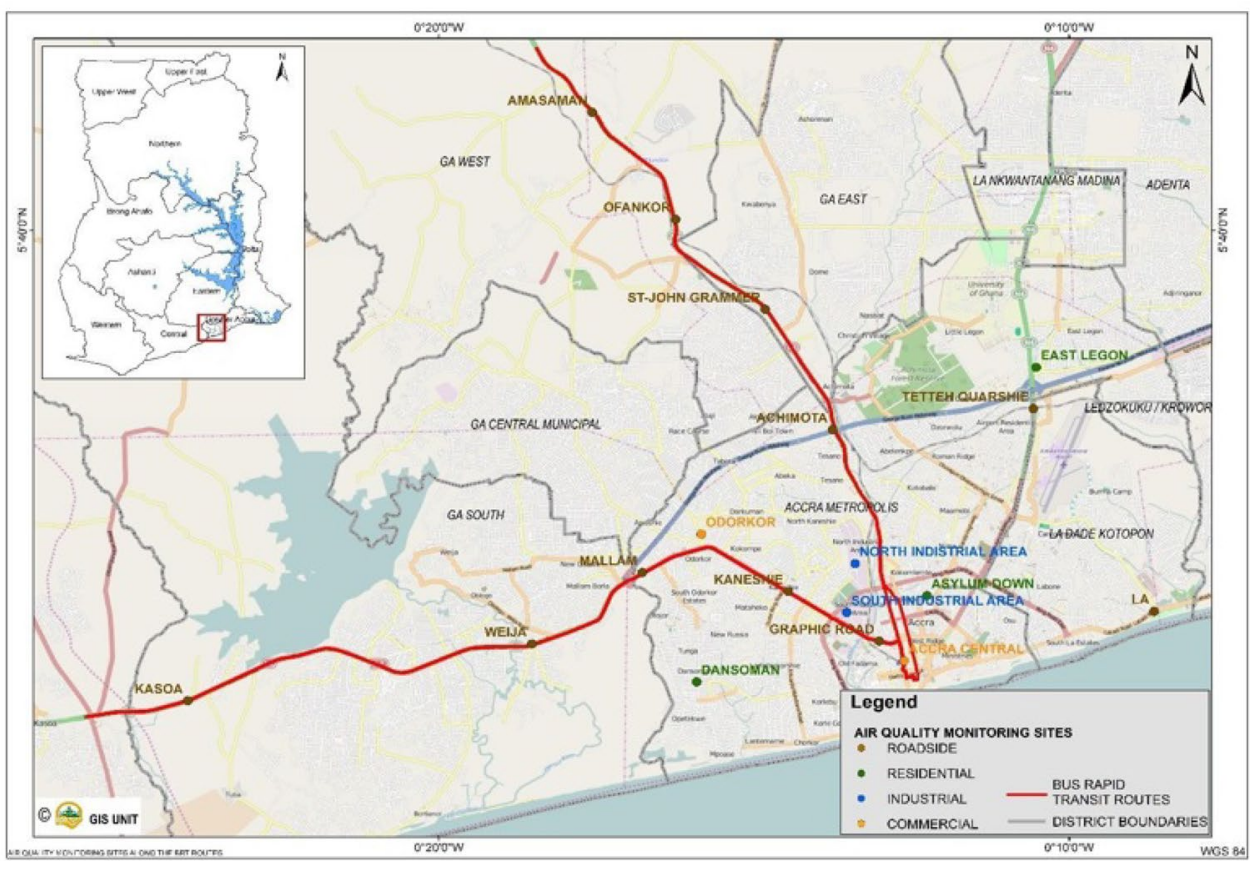

Organization was $17 \mu \mathrm{g} \mathrm{m}^{-3}$ for Liberia and $73 \mu \mathrm{g} \mathrm{m}^{-3}$ for Niger. Not surprisingly, Accra recorded $172 \mu \mathrm{g} \mathrm{m}^{-3} \mathrm{PM}_{10}$ pollution in 2015 with 2800 deaths due to air pollution. Mortality due to air pollution per 100,000 persons was 203.8. Senegal recorded the least with 160.7 and Sierra Leone the highest of 324.1 within the region. Probability of mortality from non-communicable diseases including cardio-vascular disease, diabetes, chronic respiratory disease, and cancer was $20.8 \%$. Liberia again recorded the least with $17.6 \%$ and the highest was Sierra Leone with $30.5 \%$. It is estimated that air pollution mortality in Ghana will rise to 4500 persons by 2030 if concrete actions are not taken to purge ambient air of toxins.

Passengers are becoming increasingly aware of the dangers of emissions exposure and are making safer choices whenever possible. Hotor [34] found traffic congestion as a key determinant in the choice of passenger transport. The predominance of high polluting vehicles in congested areas portends large amounts of hazardous pollutants. Hence, apart from time and convenience, road traffic also increases a passenger's exposure to harmful air pollutants and hence the risk of adverse health.

\subsubsection{Responses from vulnerable road users}

We present below responses from interviews we conducted with vulnerable road users including roadside shop attendants, hawkers, pedestrians, and residents. We set out find out the emission and risk perception of road vehicles by road users. We also engaged drivers, driver unions and in-car users to understand the drivers of a policy shift in road transport. The findings are discussed below.

$78 \%$ of vulnerable road users including hawkers, shoppers, and pedestrians estimated that 2 out of every 10 cars in a trafficked intersection or congested road emit smoke as shown in Fig. 6.

Vehicular smoke is dangerous to health of commuters and other road users [60]. Continuous exposure to vehicular smoke and fugitive emissions have the potential to cause coughing, wheezing, respiratory irritation and breathing difficulties and several other sub-clinical tendencies. Roadside source apportionment studies in Ghana are limited but a study by Ngo et al. [55] in Kenya identified roadside particulate pollution as occupational and domestic hazard for roadside workers and nearby homes.

Respondents were asked to list and rank risks of exposure to vehicular traffic on busy roadways. Among the risk factors, auto emissions, noise and heat recorded the highest indices as shown in Fig. 7. Overall, vehicular noise pollution was reported at $78 \%$ followed by vehicular emissions at $75 \%$.

Travel behaviour theory postulated by Buehler [10] shows that travellers tend to maximise travel utility and minimise travel time and cost. Responses from the interviews indicate that intra-city commercial bus transport services in Ghana offer limited utility value and convenience. The higher proliferation of private light-duty vehicles in Ghana can partly be attributed to the quest for the combined net-benefits of personalized utility, reduced travel time and convenience. On the other hand, cost was a major consideration for persons using 
Fig. 6 On-road vehicular emission perception from road users

Fig. 7 Risk rating of no-motorised road users
Estimated smoking rating of cars by respondents

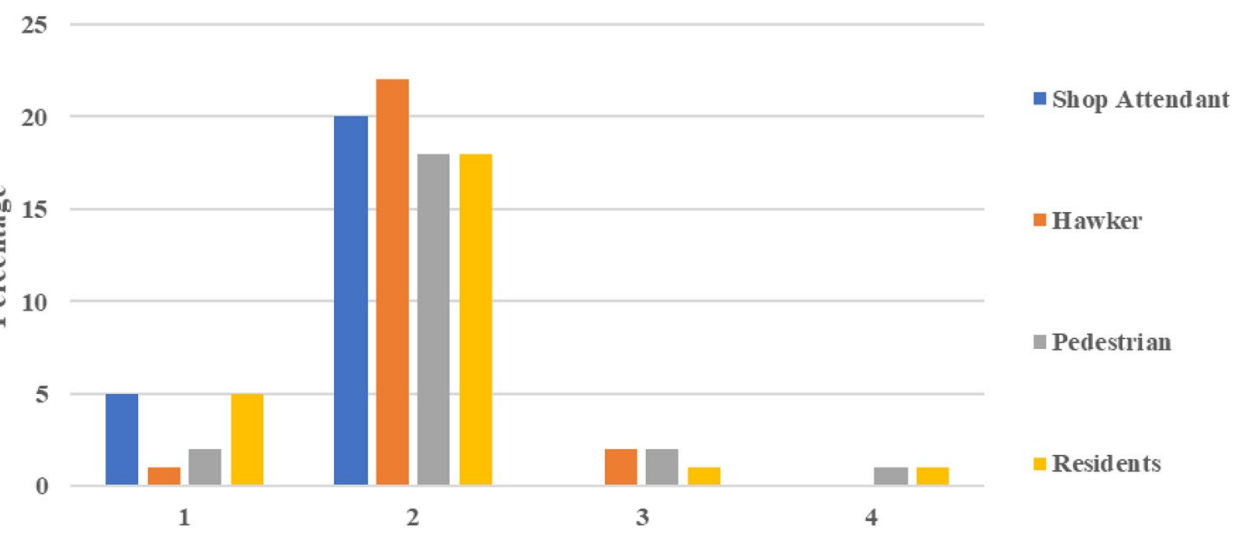

Number of cars out of 10

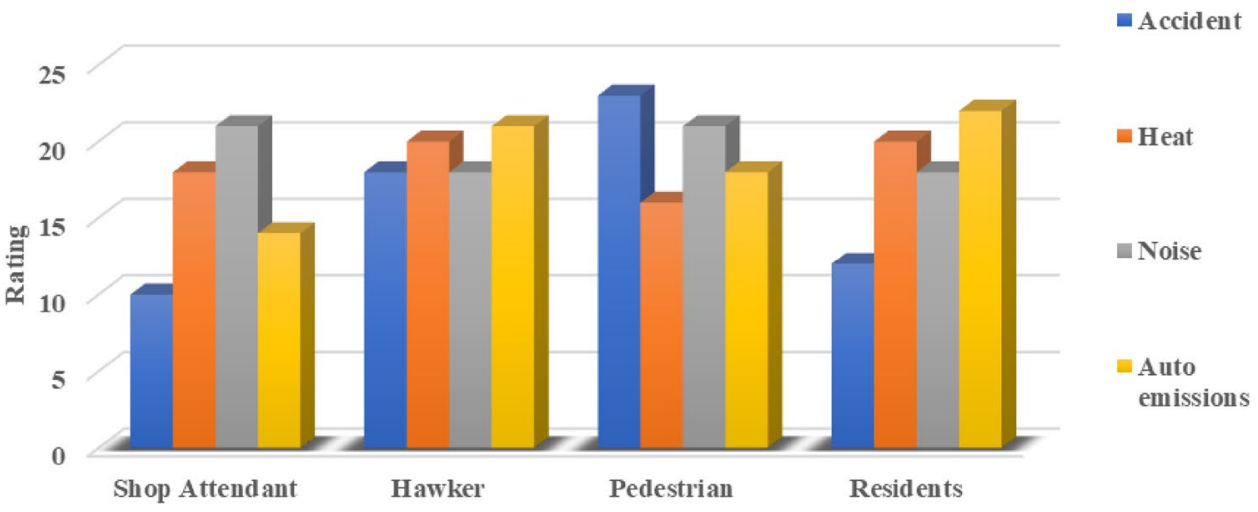

Respondent

\section{Influencers of Vehicular Use in Ghana}

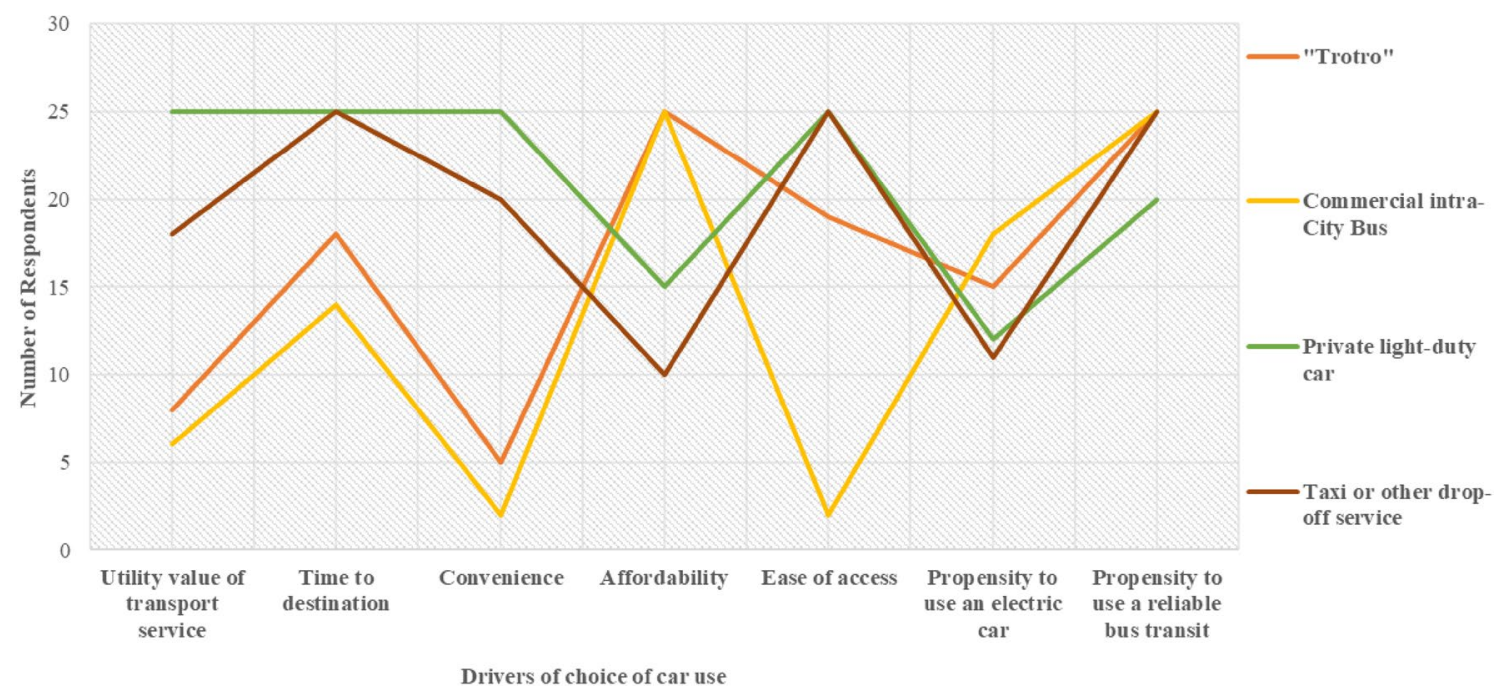

Fig. 8 Drivers of vehicular use in Accra 
commercial intra-city buses as they are deemed to be relatively cheaper. Overall, travel time $(82 \%)$, cost $(75 \%)$ and accessibility (75\%) were the largest considerations in the choice of vehicular use as shown in Fig. 8. Given the luxury of a reliable and convenient public mass transport service, $95 \%$ of respondents were willing to use.

Personalized light-duty vehicle users showed less propensity to use electric cars than their peers on public transport systems. Respondents were concerned about cost, safety, power security and accessible charging systems in an electric car regime.

Driver Unions were unanimous in declaring their support for a transport policy that limits emissions if the policy will not impose extra cost on their operations as presented in Table 3.

They claim the government is at liberty to introduce any reliable transport system provided they are not crowded out of business. They are willing to partner government implement such a policy if proper incentives and financial remunerations are agreed between the parties. As the GPRTU Chairman puts it:

Government and private road transporters have been partners pre-independence in the transport sector. Whilst Government owned public transport services have not been sustainable over the years, the private sector continues to play a domineering role. We welcome any proposal that will improve the environment and human health but hope such will not put undue financial burden on our members.

Similar sentiments were expressed by the other driver unions. They all acknowledged the potential harm of vehicular emissions and agree that there should be some form of regulation by the responsible agencies. Responses from drivers at some designated lorry terminals was no different from the Union executives. They are concerned about the perceptible ambient levels of vehicular pollutants at their stations and hope there are mechanisms to ameliorate the situation. Figure 9 summarises the

Table 3 Driver assessment of current emissions status

\begin{tabular}{l}
\hline Driver assessment of current status \\
$\begin{array}{ll}\text { Current tax regime prorates the import duty depending on the age of the car. Is the current tax regime on automo- } \\
\text { bile vehicle importation favorable to you? }\end{array}$ \\
Do you think it is environmentally friendly? \\
Do you think it is sustainable? \\
According to DVLA, Ghana's fleet is largely composed of high emitting types. Does this situation sit well with you? \\
Would you like a policy shift to reduce emissions from cars?
\end{tabular}

Fig. 9 Driver and union acceptability of policy proposals

\section{Acceptability of policy options by drivers and driver unions}

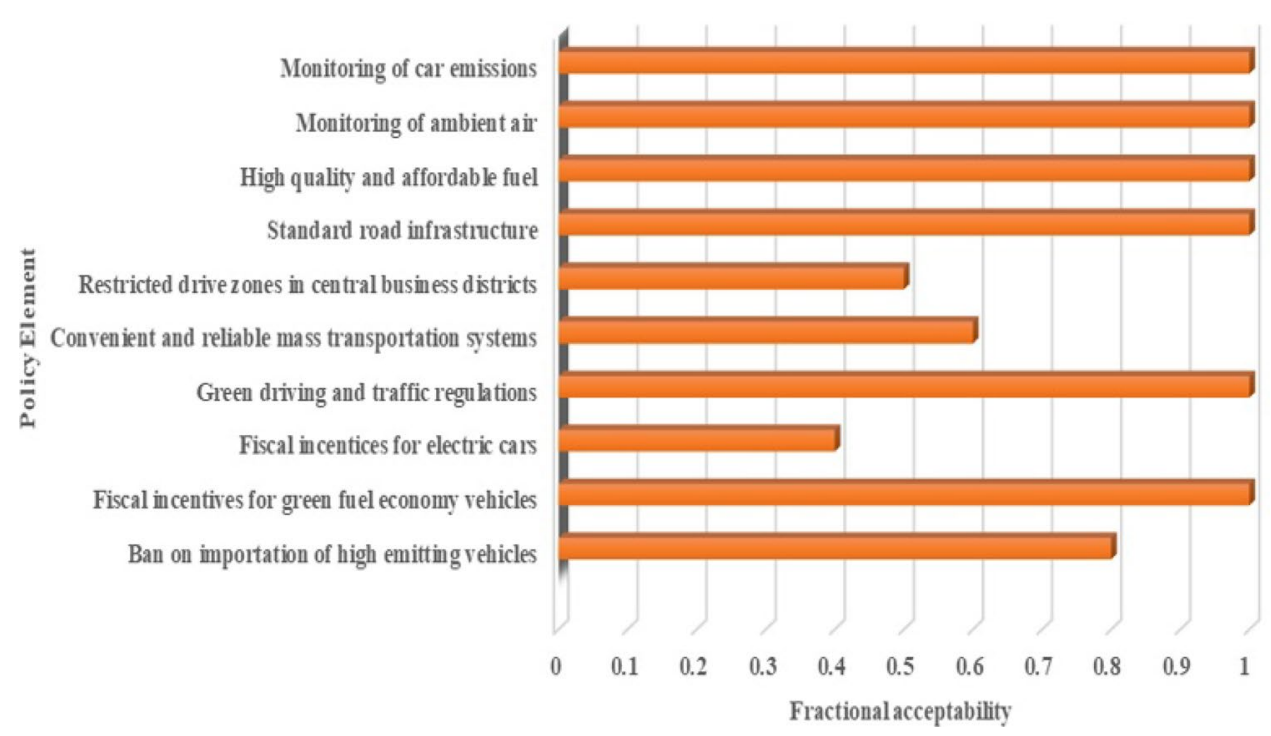

SN Applied Sciences 
acceptability rating of policy indicators by drivers and unions.

The highest ratings were reported for monitoring of ambient air and vehicle emissions, affordable and quality fuels, standard road infrastructure, green driving and traffic regulations, and fiscal incentives for importation of fuel economy vehicles. $80 \%$ of respondents favored a ban on old and high emitting vehicles. Acceptability for electric vehicles among drivers was low due mainly to historical poor power assurance, and uncertainty in guaranteed charging bays.

\section{Conclusion}

There is no specific policy in Ghana that recognises the integrated role of vehicular emissions, energy use, and climate change, and their impact on the environment and human health. This study revealed the disjointed scope of regulatory agencies and an isolated policy regime amongst them. Roadside emissions are high as most cars are outdated and without emission control technologies. The need for a specific policy in response to automotive vehicle emissions in general, and particulate matter in particular in Ghana has been acknowledged by all respondents. There is the need to link and coordinate the policies in key sectors such as transport, environment and energy in order to achieve the full benefits of this policy proposal. We observed that government needs to engage private motor vehicle owners, drivers and driver unions for the successful implementation of policies that seek to address green fuel economy, intra-city mass transport, and vehicle testing and fiscal aspects of vehicle importation. With the implementation of AFRI-4 fuel standards, it is time to introduce new policies that will limit new vehicle importations to Euro 4 standard and above. Such policies must provide fiscal incentives to change purchasing behaviours towards green technologies, comprehensive emissions monitoring and green fuel options.

\section{Compliance with ethical standards}

Conflict of interest On behalf of all authors, the corresponding author states that there is no conflict of interest.

\section{References}

1. Ackom G (2018) Number of vehicles registered between 20082017. Driver and Vehicle Licensing Authority, Ghana, Accra

2. Akumu J (2014) Improving air quality in African cities. UN Environment, Nairobi
3. Akumu J (2017) Promoting cleaner and more fuel efficient vehicles in Africa. UN Environment, Nairobi

4. Arku RE, Vallarino J, Dionisio KL, Willis R, Hyunok C, Wilson GJ et al (2008) Characterizing air pollution in two low income neighbourhoods in Accra. Sci Total Environ 402:217-231

5. Banister D (2008) The sustainable mobility paradigm. Transp Policy $15: 73-80$

6. Bin $\mathrm{H}$, Li-Wen $\mathrm{H}$, Zhipeng $\mathrm{B}$ (2017) Human exposure assessment for air pollution. In: Dong G-H (ed) Ambient air pollution and health impact in China, vol 1017. Springer, Singapore

7. Blomstrom E, Cunningham S, Johnson N, Owren C (2009) Climate change connections: women at the forefront. United Nations Population Fund, Washington, DC

8. Borrego C, Tchepel O, Costa AM, Martins H, Ferreira J, Miranda Al (2006) Traffic-related particulate air pollution exposure in urban areas. Atmos Environ 40:7205-7214

9. Bowe B, Xie Y, Li T, Yan Y, Xian H, Al-Aly Z (2018) The 2016 global and national burden of diabetes mellitus attributable to $\mathrm{PM}_{2.5}$ air pollution. Lancet Planet Health 2:e301-e312

10. Buehler R (2010) Transport policies, automobile use, and sustainable transport: a comparison of Germany and the United States. J Plan Educ Res 30:76-93

11. Charron A, Harrison RM (2005) Fine (PM2.5) and coarse (PM2.510) particulate matter on a heavily trafficked London highway: sources and processes. Environ Sci Technol 39:7768-7776

12. Dionisio K, Hughes AF, Vallarino J, de Castro MC (2014) Personal particulate matter exposures and locations of students in four neighbourhoods in Accra, Ghana. J Expo Sci Environ Epidemiol 25(6):557-566

13. Dora C (1999) A different route to health: implications of transport policies. BMJ 318:1686-1689

14. Doug V (2016) Transportation emissions roll over power sector emissions. 2019. Centre for Climate and Energy Solutions, Arlington, VA

15. Environmental Protection Agency (2011) Ghana's second national communication to the UNFCCC. EPA, Accra

16. Environmental Protection Agency (2015) Ghana's third national communication report to the UNFCCC. Ghana EPA, Accra

17. Environmental Protection Agency (2017) Roadmap for the promotion of cleaner buses in Accra, Ghana. Ghana EPA, Accra

18. Environmental Protection Agency (2017) State of Ghana's environment: 2016 report. In: Tal (ed) Ministry of Environment Science. EPA, Ghana, Accra

19. Environmental Protection Agency (2018) Greater Accra region air quality management plan. Ghana EPA, Accra

20. Eze IC, Schaffner E, Fischer E, Schikowski T, Adam M, Imboden $M$ et al (2014) Long-term air pollution exposure and diabetes in a population-based Swiss cohort. Environ Int 70:95-105

21. Faiz A, Sinha K, Walsh M, Varma A (1990) Automotive air pollution: issues and options for developing countries, vol 492. World Bank Publications, Washington

22. Gakenheimer R (1999) Urban mobility in the developing world. Transp Res Part A Policy Pract 33:671-689

23. Ghana Energy Commission (2018) 2018 energy outlook for Ghana. Energy Commission, Accra

24. Ghana Energy Commission (2018) National energy statistics: 2008-2017. Ghana Energy Commission, Accra

25. Ghana Energy Commission (2019) Ghana renewable energy masterplan. Energy Commission, Accra

26. Ghana Standards Authority (2017) GS140:2017: petroleum and petroleum products-specifications for petrol (motor gasoline). Ghana Standards Authority, Accra

27. Government of Ghana (1996) Constitution of the Republic of Ghana. Assembly Press, Accra

28. Gwilliam K, Kojima M, Johnson T (2004) Reducing air pollution from urban transport. World Bank, Washington, DC 
29. Habtezion S (2016) Gender and climate change: gender and sustainable energy. United Nations Development Programme, New York

30. Hanna R, Oliva P (2016) Implications of climate change for children in developing countries. Future Child 26:115-132

31. Haq G, Schwela D (2012) Transport and environment in subSaharan Africa. Stocholm Environment Institute, University of York, London

32. HEI/IHME (2019) State of global air 2019: a special report on global exposure to air pollution and its disease burden. Health Effects Institute, Boston, MA

33. Honda T, Pun VC, Manjourides J, Suh H (2017) Associations between long-term exposure to air pollution, glycosylated hemoglobin and diabetes. Int J Hyg Environ Health 220:1124-1132

34. Hotor DE (2016) The use of public transport services by residents in the Accra metropolitan area. MPhil, Department of Geography and Resource Development, University of Ghana, Accra

35. Iddrisu I, Bhattacharyya SC (2015) Ghana's bioenergy policy: is $20 \%$ biofuel integration achievable by 2030 ? Renew Sustain Energy Rev 43:32-39

36. Inderwildi O, King D (2012) Energy, transport, \& the environment: addressing the sustainable mobility paradigm. Springer, Oxford

37. Jacquemin B, Kauffmann F, Pin I, Le Moual N, Bousquet J, Gormand $F$ et al (2012) Air pollution and asthma control in the Epidemiological study on the genetics and environment of asthma. $\mathrm{J}$ Epidemiol Community Health 66:796-802

38. Keyah O (2017) Analysis of the governance framework for vehicular air pollution abatement in Kenya: a case study of Nairobi City. MSc, Wangari Maathai Institute for Peace and Environmental Studies, University of Nairobi, Nairobi, Kenya

39. Keyvanfar A, Shafaghat A, Muhammad N, Ferwati M (2018) Driving behaviour and sustainable mobility-policies and approaches revisited. Sustainability 10:1152

40. Kinney PL (2008) Climate change, air quality, and human health. Am J Prev Med 35:459-467

41. Knippertz P, Evans MJ, Field PR, Fink AH, Liousse C, Marsham JH (2015) The possible role of local air pollution in climate change in West Africa. Nat Clim Change 5:815-822

42. Krzyżanowski M, Kuna-Dibbert B, Schneider J (2005) Health effects of transport-related air pollution. WHO Regional Office Europe, Copenhagen

43. Lelieveld J, Haines A, Pozzer A (2018) Age-dependent health risk from ambient air pollution: a modelling and data analysis of childhood mortality in middle-income and low-income countries. Lancet Planet Health 2:e292-e300

44. Mage D, Zali O (1992) Motor vehicle air pollution: public health impact and control measures. World Health Organization, Geneva

45. Marcu A (2016) International cooperation under Article 6 of the Paris agreement: reflections before SB 44. International Centre for Trade and Sustainable Development (ICTSD), Geneva

46. Mbandi AM, Böhnke JR, Schwela D, Vallack H, Ashmore MR, Emberson L (2019) Estimating on-road vehicle fuel economy in Africa: a case study based on an urban transport survey in Nairobi, Kenya. Energies 12:1177

47. McCarthy MC, Eisinger DS, Hafner HR, Chinkin LR, Roberts PT, Black KN et al (2006) Particulate matter: a strategic vision for transportation-related research. ACS Publications, Washington

48. McGranahan G, Murray F (2003) air pollution and health in rapidly developing countries. Earthscan Publications Ltd, Stockholm

49. Meijer J, Berg AD (2010) Handbook of environmental policy. Nova Science Publishers Inc., New York
50. Mensah GS, Kemausuor F, Brew-Hammond A (2014) Energy access indicators and trends in Ghana. Renew Sustain Energy Rev 30:317-323

51. Mensah JT, Marbuah G, Amoah A (2016) Energy demand in Ghana: a disaggregated analysis. Renew Sustain Energy Rev 53:924-935

52. Ministry of Planning (2018) Medium term expenditure framework. Ministry of Planning, Accra

53. Ministry of Transport (2016) Vehicle popultaion and growth rate. Minstry of Transport, Ghana, Accra

54. Nare H, Kamakate F (2017) Developing a roadmap for the adoption of clean fuel and vehicle standards in Southern and Western Africa. International Council on Clean Transportation, Washington, $\mathrm{DC}$

55. Ngo NS, Gatari M, Yan B, Chillrud SN, Bouhamam K, Kinneym PL (2015) Occupational exposure to roadway emissions and inside informal settlements in sub-Saharan Africa: a pilot study in Nairobi, Kenya. Atmos Environ 111:179-184

56. O'Donovan G, Cadena-Gaitán C (2018) Air pollution and diabetes: it's time to get active! Lancet Planet Health 2:e287-e288

57. Obeng-Odoom F (2010) Drive left, look right: the political economy of urban transport in Ghana. Int J Urban Sustain Dev $1: 33-48$

58. OECD (2016) The economic consequences of outdoor air pollution. OECD, Paris

59. Ofosu F, Aboh I, Bamford S (2016) Ambient air PM10 particulate levels at Ashaiman near Tema in Ghana. Br J Appl Sci Technol $12: 1-14$

60. Ogur E, Kariuki S (2014) Effect of car emissions on human health and the environment. Int J Appl Eng Res 21:11121-11128

61. Okyere DK (2012) Sustainability of the urban transport system of Kumasi. MPhil, College of Architecture and Planning, Kwame Nkrumah University of Science and Technology, Kumasi

62. PAGE (2015) Ghana: green industry and trade assessment. Partnership for Action on Green Economy, Accra

63. Prithipaul D, Allock A, Juggurnath A (2016) Using better quality fuel to mitigate vehicle emissions: the case of Mauritius. Ministry of Environment, Sustainable Development, and Disaster and Beach Management, Port Loise

64. Riediker M, Williams R, Devlin R, Griggs T, Bromberg P (2003) Exposure to particulate matter, volatile organic compounds, and other air pollutants inside patrol cars. Environ Sci Technol 37:2084-2093

65. Roy R (2016) The cost of air pollution in Africa. OECD, Paris

66. Sandow B (2016) Diurnal rhythms of ambient air pollution due to vehicular traffic in Accra. MPH, School of Public Health, University of Ghana

67. Schutt DM (2015) Sustainable development goals. Catholic Development Agency for England and Wales (CAFOD), Cardiff

68. Sheffield P, Landrigan P (2011) Global climate change and children's health: threats and strategies for prevention. Environ Health Perspect 119:291-298

69. Simons A, Nunoo S (2009) Liquefied petroleum gas as an alternative vehicle fuel in Ghana. Pet Sci Technol 27:2223-2233

70. Solarin SA, AI-Mulali U, Musah I, Ozturk I (2017) Investigating the pollution haven hypothesis in Ghana: an empirical investigation. Energy 124:706-719

71. Sourangsu C, Sagnik D (2018) Air quality in changing climate: implications for health impacts. In: Rais A, Cosimo P (eds) Climate change and air pollution: the impact on human health in developed and developing countries. Springer, Cham

72. Sulemana I (2012) Assessing over-aged car legislation as an environmental policy law in Ghana. Int J Bus Soc Sci 3:57-64

73. Sulemana R (2017) Assessment of heavy metal concentrations in particulate matter (PM10) in the ambient air of selected roadsides in the Accra Metropolis. MSc, Department of nvironmental 
Science, Kwame Nkrumah University of Science and Technology, Kumasi, Ghana

74. United Nations Organization (2018) The sustainable development goals report 2018. United Nations, New York

75. Wardoyo AYP, Dharmawan HA (2019) Developing reheated motocycle exhaust for PM2.5 emission. Int J Geomate 16:109-116

76. Wargo J, Wargo L, Alderman N (2006) The harmful effects of vehicle exhaust: a case for policy change. Environment and Human Health Inc., North Haven, CT

77. Wedeman N, Petruney T (2018) Invest in girls and women to tackle climate change and conserve the environment. Deliver for Good, New York

78. Weisbrod G (2008) Models to predict the economic development impact of transportation projects: historical experience and new applications. Ann Reg Sci 42:519-543

79. Wittneben B, Bongardt D, Dalkmann H, Sterk W, Baatz C (2009) Integrating sustainable transport measures into the clean development mechanism. Transp Rev 29:91-113

80. World Health Organization (2000) Guidelines for air quality. WHO, Geneva
81. World Health Organization (2018) 9 out of 10 people worldwide breath polluted air, but more countries are taking action. 2019. WHO, Geneva

82. World Health Organization (2018) World health statistics 2018: monitoring health for the SDGs. World Health Organization, Luxembourg

83. Yang B-Y, Qian Z, Li S, Chen G, Bloom MS, Elliott M et al (2018) Ambient air pollution in relation to diabetes and glucosehomoeostasis markers in China: a cross-sectional study with findings from the 33 communities Chinese Health Study. Lancet Planet Health 2:e64-e73

84. Zhou Z, Dionisio KL, Verissimo TG, Kerr AS, Coull B, Arku RE et al (2013) Chemical composition and sources of particle pollution in affluent and poor neighborhoods of Accra, Ghana. Environ Res Lett 8:1-9

Publisher's Note Springer Nature remains neutral with regard to jurisdictional claims in published maps and institutional affiliations. 